\title{
Improved basic life support skills and patient transportation at ambulance drivers in Medan Tuntung and Medan Sunggal area to improve patient safety

\author{
Yetty Machrina $^{1 *}$, Kamal Basri Siregar ${ }^{1}$, Nuraiza Meutia ${ }^{1}$, Gema Nazri Yanni ${ }^{1}$, Yunita Sari \\ Pane $^{1}$ \\ Indonesia \\ *Email: yetty@usu.ac.id
} \\ ${ }^{1}$ Department of general medicine, Faculty of medical, Universitas Sumatera Utara, Medan,
}

\begin{abstract}
The technique of providing basic and quick life support (BHD) and transportation to patients with cardiac and pulmonary arrest can save a patient's life. An ambulance driver as one of the ambulance personnel should be equipped with the two forms of skills above. The aim of community service is to increase the capacity of ambulance drivers in terms of providing basic life support skills and patient transportation to improve patient safety. This training was held in September 2019, at the H. Adam Malik General Hospital Training Center Installation Medan, with 24 participants. The training is carried out with 2 methods, namely exposure to BHD theory and BHD skills training. The knowledge and skills of participants before and after the training were assessed. Pre and post assessment results were analyzed using paired t-test with a significance level of $p<0.05$ Ambulance drivers in the Medan Tuntung and Medan Sunggal area are mostly over 30 years old, with most working as ambulance drivers for more than 5 years. The most recent level of education is high school graduation or equivalent. The results of statistical analysis using paired t-test, obtained a significant difference in the knowledge of ambulance drivers about basic life support theory before and after training $(p=0.000)$. Likewise, ambulance driver skills in providing basic life support for adult patients, infants and children were significantly different before and after training $(\mathrm{p}=0.000)$. Training in basic life support skills and patient transportation can increase the capacity of ambulance drivers in providing basic life support..
\end{abstract}

\section{Keyword: Basic living assistance, Patient transportation}

\begin{abstract}
Abstrak
Teknik memberikan bantuan hidup dasar (BHD) yang cepat dan tepat serta transportasi terhadap pasien dengan keadaan henti jantung dan paru dapat menyelamatkan jiwa pasien. Supir ambulans sebagai salah seorang personil ambulans sebaiknya dibekali dengan kedua bentuk keterampilan di atas. Tujuan pengabdian masyarakat ini adalah meningkatkan kapasitas supir ambulans dalam hal memberikan keterampilan bantuan hidup dasar dan transportasi pasien untuk meningkatkan patient safety. Pelatihan ini dilaksanakan pada bulan September 2019, di Instalasi Diklat RSUP H. Adam Malik Medan, dengan jumlah peserta sebanyak 24 orang. Pelatihan dilakukan dengan 2 metode, yaitu pemaparan teori BHD dan pelatihan keterampilan BHD. Pengetahuan dan keterampilan peserta sebelum dan sesudah pelatihan dinilai. Hasil penilaian pre dan post dianalisis dengan menggunakan uji pair-t test dengan tingkat kemaknaan $\mathrm{p}<0.05$. Supir ambulans di kawasan Medan Tuntungan dan Medan Sunggal sebagian besar berusia di atas 30 tahun, dengan lama bekerja sebagai supir ambulans sebagian besar lebih dari 5 tahun. Tinggkat pendidikan terakhir paling banyak adalah tamat SMA atau sederajatnya. Hasil analisa statistik dengan menggunakan uji pair-t test, diperoleh perbedaan yang bermakna pengetahuan supir ambulans tentang teori bantuan hidup dasar sebelum dan sesudah pelatihan $(\mathrm{p}=0.000)$. Demikian pula halnya keterampilan supir ambulans dalam memberikan bantuan hidup dasar pada pasien dewasa, bayi dan anak-anak berbeda bermakna sebelum dan sesudah pelatihan $(\mathrm{p}=0.000)$. Pelatihan keterampilan bantuan hidup dasar dan transportasi pasien dapat meningkatkan kapasitas supir ambulans dalam memberikan bantuan hidup dasar..
\end{abstract}

Kata Kunci: Bantuan hidup dasar, Transportasi pasien 


\section{PENDAhuluan}

\subsection{Latar belakang}

Henti jantung dan paru bisa terjadi dimana saja dan kapan saja, baik di dalam kawasan rumah sakit, luar rumah sakit, atau bahkan di dalam kendaraan termasuk ambulans. Bantuan hidup dasar harus dimulai dalam waktu 4 menit setelah serangan untuk mencegah terjadinya kematian batang otak yang berhentinya denyut jantung dan gerakan pernapasan. (Mauri, 2015) Bantuan hidup dasar adalah usaha untuk memperbaiki dan/atau memelihara jalan napas, pernapasan dan sirkulasi serta kondisi darurat yang terkait. Bantuan hidup dasar terdiri dari penilaian awal, penguasaan jalan napas, ventilasi pernapasan dan kompresi dada. (Lim SH, 2017). Dengan melakukan bantuan hidup jantung dasar dengan baik dan tepat, maka henti jantung dapat segera diatasi, fungsi jantung paru dapat dipertahankan dan otak dapat dijaga dengan baik, karena suplai darah ke otak dapat terpelihara sehingga kerusakan otak yang irreversible akibat kekurangan oksigen dapat dicegah. (Kleinman, 2015)

Bantuan hidup dasar dapat dilakukan oleh siapa saja, tidak saja tenaga medis dan paramedik tetapi juga orang awam. Supir ambulans merupakan orang awam yang paling dekat dengan pasien selain perawat dan dokter pada saat proses evakuasi dan transportasi pasien. Pelayanan transportasi pasien rujukan dengan kondisi tertentu antar fasilitas kesehatan merupakan salah satu bentuk pelayanan ambulans. Upaya atau kegiatan menjaga kestabilan kondisi pasien untuk kepentingan dan keselamatan pasien (patient safety) menjadi prioritas dalam proses transportasi (PERMENKES, 2013).

Pasien emergensi baik yang diakibatkan oleh kecelakaan lalu lintas ataupun penyakit terdahulu berisiko untuk terjadinya kematian pada saat proses transportasi sehingga pengenalan, penanganan dan manajemen pada pasien emergensi sangat fundamental diperlukan (Colledge, Walker dan Ralston, 2010). Proses transportasi sangat berpengaruh terhadap pasien emergensi melalui 2 mekanisme, yaitu melalui perpindahan pasien selama proses transportasi, akselerasi dan deselerasi, perubahan postur dan lingkungan perawatan serta media perawatan yang digunakan pasien dapat memperberat stress fisiologis pada pasien emergensi (Fanara et al, 2010). Aspek transportasi pasien merupakan salah satu keterampilan yang seharusnya juga dimiliki oleh supir ambulans. Sehingga bila sewaktu waktu dibutuhkan, supir ambulans dapat membantu meringakan tugas dokter dan perawat dalam hal evakuasi dan transportasi.

Di kawasan Medan Tuntungan dan Medan Sunggal terdapat rumah sakit tipe A dan tipe B yang sering menjadi pusat rujukan dari rumah sakit lain. Kedua rumah sakit ini memiliki sejumlah personil ambulans yang siap melaksanakan berbagai bentuk pelayanan ambulans baik transportasi pasien di internal rumah sakit, antar rumah sakit maupun transportasi pasien ke luar daerah. Latar belakang pendidikan supir ambulans yang sebagian besar bukan sarjana serta bukan berasal dari orang kesehatan, menyebabkan supir ambulans kurang terpapar dengan ilmu kegawat daruratan.

\subsection{Tujuan}

Tujuan dilaksanakannya pengabdian masyarakat ini adalah untuk meningkatkan keterampilan bantuan hidup dasar dan transportasi pasien pada supir ambulans di kawasan Medan Tuntungan dan Medan Sunggal untuk meningkatkan patient safety.

\subsection{Manfaat}

Manfaat yang diperoleh dari pengabdian masyarakat ini adalah adanya peningkatan pengetahuan dan keterampilan supir ambulans dalam memberikan bantuan hidup dasar pada pasien dewasa, bayi dan anak. Serta memiliki pengetahuan yang benar tata cara memindahkan pasien dan memposisikan pasien pada saat proses transportasi. 


\section{METODE PELAKSANAAN}

Kegiatan pelatihan keterampilan bantuan hidup dasar dan trasnportasi pada supir ambulans di kawasan Medan Tuntungan dan Medan Sunggal, dilaksanakan di Instalasi Diklat RSUP H. Adam Malik Medan pada bulan September 2019 dengan diikuti sebanyak 24 orang supir ambulans.

Peserta pelatihan diberikan materi tentang bantuan hidup dasar dan transportasi pasien pada pasien dewasa, bayi dan anak, sistem penanggulangan gawat darurat terpadu (SPGDT) dan peraturan lalu lintas yang berkaitan dengan ambulans. Peserta juga diajarkan teknik memberikan bantuan hidup dasar dan teknik transportasi pasien yang benar. Pengetahuan mengenai teori dan keterampilan supir ambulans tentang bantuan hidup dasar sebelum dan sesudah pelatihan dinilai. Untuk menilai pengetahuan digunakan test tertulis, sedangkan untuk menilai keterampilan digunakan check list observasi. Analisis perbedaan pengetahuan dan keterampilan sebelum dan sesudah pelatihan, digunakan uji paired-t test dengan nilai kemaknaan $\mathrm{p}<0,05$.

\section{HASIL DAN PEMBAHASAN}

\subsection{HASIL}

\subsubsection{Karakteristik mitra pengabdian masyarakat}

Karakteristik peserta pelatihan (mitra pengabdian masyarakat) bersadarkan usia, tingkat pendidikan dan lama bekerja sebagai supir ambulans dapat dilihat pada tabel.1

Berdasarkan tabel.1 diketahui bahwa rata-rata usia supir ambulan di kawan Medan Tuntungan dan Medan Sunggal di atas 30 tahun (83,4\%), dengan lama kerja sebagian besar lebih dari 5 tahun $(54,2 \%)$ dan pendidikan terakhir sebagian besar adalah tamat SMA dan sederajatnya

\begin{tabular}{ccc}
\hline & $\begin{array}{c}\text { Frekuensi } \\
(\mathrm{n})\end{array}$ & $\begin{array}{c}\text { Persentase } \\
(\%)\end{array}$ \\
\hline Umur (tahun) & & \\
$\cdot \quad 20-30$ & 4 & 16,6 \\
- $\quad 30-40$ & 10 & 41,7 \\
- $>40$ & 10 & 41,7 \\
Lama kerja & & \\
- $\quad 5$ tahun & 11 & 45,8 \\
- > 5 tahun & 13 & 54,2 \\
Pendidikan & & \\
- SD & 0 & 0 \\
- SMP & 5 & 20,9 \\
- SMA & 18 & 75,0 \\
D3 & 1 & 4,1
\end{tabular}

Tabel.3.1 Karakteristik supir ambulan (mitra pengabdian masyarakat)

\subsubsection{Perbedaan pengetahuan mitra tentang bantuan hidup dasar sebelum dan sesudah pelatihan}

Hasil uji teori tentang memberikan bantuan hidup dasar pada pasien dewasa, bayi dan anak sebelum dan sesudah pelatihan, diuji dengan menggunakan uji dependent t-test, dapat dilihat pada tabel.2 dibawah ini 


\begin{tabular}{lccc}
\hline & \multicolumn{3}{c}{ Nilai Teori } \\
\cline { 2 - 4 } & Mean & Mean & Mean \\
Pre test & 43.31 & 15.97 & $0.000^{*}$ \\
Post test & 69.98 & 15.28 & \\
\hline *p $<0,05$ & & &
\end{tabular}

Tabel. 3.2 Perbedaan pengetahuan mitra tentang bantuan hidup dasar sebelum dan sesudah pelatihan

Berdasarkan tabel.2 di atas diketahui bahwa pelatihan yang diberikan mampu meningkatkan pengetahuan mitra mengenai bantuan hidup dasar secara bermakna.

\subsubsection{Perbedaan keterampilan mitra dalam memberikan bantuan hidup dasar pada dewasa, bayi dan anak sebelum dan sesudah pelatihan}

Hasil observasi ujian praktek memberikan bantuan hidup dasar pada pasien dewasa, dan bayi yang dilakukan oleh mitra, sebelum dan sesudah pelatihan, diuji dengan paired t-test dapat dilihat pada tabel.3 di bawah di bawah ini

\begin{tabular}{lccc}
\hline & \multicolumn{3}{c}{ Nilai Praktek } \\
\cline { 2 - 4 } & Mean & SD & P value \\
Pre test & 43.31 & 13.16 & $0.000^{*}$ \\
Post test & 100 & & \\
$* \mathrm{p}<0,05$ & & &
\end{tabular}

Tabel. 3.3 Perbedaan keterampilan mitra dalam memberikan bantuan hidup dasar pada dewasa, bayi dan anak sebelum dan sesudah pelatihan

Berdasarkan tabel.3 di atas diketahui bahwa pelatihan yang diberikan mampu meningkatkan keterampilan mitra dalam memberikan bantuan hidup dasar pada pasien dewasa dan bayi. Keterampilan mitra setelah diberikannya pelatihan meningkat secara bermakna.

\subsection{PEMBAHASAN}

Menurut kamus besar Bahas Indonesia keterampilan adalah kecakapan untuk menyelesaikan tugas. Keterampilan kerja merupakan keterampilan yang dimiliki oleh pegawai dapat bekerja dengan lebih baik dan mampu menggunakan fasilitas kerja yang disediakan dalam menyelesaikan tugas dan pekerjaan.

Keterampilan juga merupakan kecakapan, atau kemahiran yang dimiliki pegawai untuk melakukan suatu pekerjaan dan hanya dapat diperoleh melalui praktek, baik latihan maupun pengalaman. Iverson (2001) mengatakan keterampilan membutuhkan pelatihan dan kemampuan dasar yang dimiliki setiap orang dapat lebih membantu menghasikan sesuatu yang lebih bernilai dengan lebih cepat. Hasil pelatihan ini memperlihatkan bahwa pelatihan yang diberikan mampu meningkatkan keterampilan supir ambulans dalam memberikan bantuan hidup dasar dan transportasi pasien dewasa, bayi dan anak (tabel.3).

Menurut Notoatmojo (2007) mengatakan keterampilan merupakan aplikasi dari pengetahuan sehingga tingkat keterampilan seseorang berkaitan dengan tingkat pengetahuan. Terdapat faktorfaktor yang mempengaruhi pengetahuan, yaitu umur, tingkat pendidikan dan pengalaman. Sedangkan yang mempegaruhi keterampilan adalah motivasi, pengalaman dan keahlian.

Pada pelatihan ini, sebagian besar adalah usia produktif (tabel.1) Subri (2012) mendefinisikan usia produktif sebagai usia tenaga kerja (berusia 15- 64 tahun) dimana penduduk dalam suatu negara yang dapat memproduksi barang dan jasa jika ada permintaan terhadap tenaga mereka, dan jika mereka mau berpartisipasi dalam aktivitas tersebut. Kelompok umur angkatan kerja dibedakan 
menjadi:"muda (15-24 tahun), prima (25-60 tahun), tua (60 tahun ke atas) (Sumarsono, 2003, Subri, 2012). Sedangkan pengalaman kerja supir ambulans sebagian besar diatas 5 tahun. (tabel.1) Menurut Notoatmojo, pekerja di usia produktif akan memberikan hasil kerja yang lebih baik dibandingkan pekerja di usia non produktif. Pengalaman dalam bekerja memberikan kontribusi terhadap pengetahuan, sikap dan tindakan seseorang dalam melakukan sesuatu. Meskipun hasil penelitian Fitriantoro, 2009 mendapatkan bahwa tidak ada hubungan antara kinerja dengan usia dan lama kerja.

Kegiatan pendidikan dan pelatihan dapat menambah pengetahuan dan keterampilan tenaga kerja dalam melakukan pekerjaan dalam tugas profesinya. Kegiatan penyegaran keilmuan yang senantiasa dilakukan dapat memberikan motivasi kepada tenaga kerja untuk melakukan tugas dengan sebaik baiknya. Sebagaimana yang diperoleh oleh Fitriantoro dalam penelitiannya bahwa pelatihan dan pendidikan berkelanjutan dapat meningkatkan kualitas kerja. Pada pelatihan ini, hasil umpan balik peserta terhadap kegiatan sangat puas dan peserta mengharapkan agar dilakukan latihan berkelanjutan untuk meningkatkan lagi kapasitas mereka sebagai supir ambulans. Hasil observasi dan post test tertulis memperlihatkan bahwa motivasi dan semangat peserta dalam mengikuti kegiatan, merupakan salah satu faktor yang berperan pada kebermaknaan hasil pelatihan

\section{KESIMPULAN}

Pelatihan keterampilan bantuan hidup dasar dan transportasi pasien dapat meningkatkan kapasitas supir ambulans dalam memberikan bantuan hidup dasar.

\section{UCAPAN TERIMAKASIH}

Penulis dalam hal ini mengucapkan terima kasih kepada kepala unit kemotoran RSUP H.Adam Malik Medan yang telah membantu memfasilitasi kegiatan pengabdian masyarakat ini sehingga terlaksana dengan baik. Sumber pendanaan pengabdian masyarakat ini berasal dari Lembaga Pengabdian Masyarakat Universitas Sumatera..

\section{DAFTAR PUSTAKA}

Colledge N. R., Walker, B. R., Ralston, S., \& Davidson, S. (2010). Davidson s principles and practice of medicine. Churchill Livingstone/Elsevier,

Fanara B, Manzon C, Barbot, O., Desmettre, T., \& Capellier, G. (2010). Recommendations for the intra-hospital transport of critically ill patients. Critical Care, 14(3), R87.

Fitriantoro A. R., \& DHAR, E. S. (2009). Hubungan antara Usia dan Masa Kerja dengan Kinerja Dosen. Skripsi. Yogyakarta: Universitas Sanata Dharma.

Iverson. 2001. Memahami Keterampilan Pribadi. Bandung : CV. Pustaka

Kleinman M, Brennan E, Goldberger Z, Swor R, Terry M, Bobrow B et al. (2015). Part 5: Adult Basic Life Support and Cardiopulmonary Resuscitation Quality. Circulation. 132(18 suppl 2):S414-S435.

Lim SH, Wee FC, and Chee TS. (2017). Basic Cardiac Life Support : 2016 Singapore Guideline. Singapore Med J, Jul;58(7): 347-353 
Mauri R, Burkart R, Benvenuti C, Caputo M, Moccetti T, Del Bufalo A et al. Better management of out-of-hospital cardiac arrest increases survival rate and improves neurological outcome in the Swiss Canton Ticino. Europace. 2015;18(3):398-404. 3.

Notoatmodjo S. 2007. Pendidikan dan Perilaku. Jakarta: Rineka Cipta

Peraturan Menteri Kesehatan Republik Indonesia Nomor 71 Tahun 2013 Tentang Pelayanan Kesehatan Pada Jaminan Kesehatan Nasional diakses dari http://www.depkes.go.id/resources/download/general/PMK\%20No.\%2071\%20Th\%202013 $\% 20 \mathrm{ttg} \% 20$ Pelayanan\%20Kesehatan\%20Pada\%20JKN.pdf

Sony S. 2003. Ekonomi Manajemen Sumberdaya Manusia dan Ketenagakerjaan. Graha Ilmu. Yogyakarta.

Subri M. 2012. Ekonomi Sumber Daya Manusia. Jakarta : Raja Grafindo Persada 